\title{
Metabolic and health consequences of occupational exposure to polychlorinated biphenyls
}

\author{
A B SMITH, ${ }^{1}$ JOANNE SCHLOEMER, ${ }^{1}$ L K LOWRY, ${ }^{1}$ A W SMALLWOOD, ${ }^{1}$ \\ R N LIGO, ${ }^{\prime *}$ S TANAKA, ${ }^{1}$ W STRINGER, ${ }^{\prime}$ M JONES, ${ }^{\dagger} \dagger$ R HERVIN, ${ }^{\prime}$ AND \\ C J GLUECK ${ }^{2} \ddagger$
}

From the United States Department of Health and Human Services, Public Health Service, Center for Disease Control, National Institute for Occupational Safety and Health, Division of Surveillance, Hazard Evaluations and Field Studies, ${ }^{1}$ Robert A Taft Laboratories, and Lipid Research Centre, ${ }^{2}$ University of Cincinnati Medical Centre, Cincinnati, Ohio, USA

ABSTRACT In surveys of three groups of workers occupationally exposed to polychlorinated biphenyls (PCBs) serum PCB concentrations were quantitated as lower chlorinated biphenyls (L-PCBs) and higher chlorinated biphenyls (H-PCBs). Serum L-PCB and H-PCB concentrations were many times greater among workers employed in power capacitor manufacturing than among the general population, even comparing employees never assigned to work in PCBexposed areas. Statistically significant positive correlations of symptoms suggestive of mucous membrane and skin irritation, of systemic malaise, and altered peripheral sensation were noted with increasing concentrations of serum PCB. No clinical abnormalities attributable to exposure to PCB were observed. Serum PCB concentrations were positively and significantly correlated with glutamic-oxalacetic transaminase (SGOT), serum gamma-glutamyl transpeptidase (GGTP), and plasma triglyceride, and inversely correlated with plasma high density lipoproteincholesterol. These correlations were present across all study sites. These findings are indicative of PCBs' physiological effect on the liver, whose long-range health significance is unknown. Nevertheless, the consistent positive association of serum PCB with plasma triglyceride and negative association with plasma HDL-cholesterol may have long-turm cardiovascular consequences.

Polychlorinated biphenyls (PCBs), a class of chlorinated aromatic hydrocarbon compounds, have become widely dispersed in the environment. Manufactured in the United States from 1929 to 1977 by the Monsanto Industrial Chemicals Company and marketed under the tradename Aroclor, the growth in their annual sales to a peak of 85054000 pounds in $1970^{1}$ is evidence of their versatility and of a past general lack of concern for their potential toxicity. After a series of mishaps that resulted in contamination by PCBs of human and

*Present address: Medical Division, E I duPont de Nemours and Co, Inc, Wilmington, Delaware.

†Present address: Kaiser Aluminum and Chemical Company, Ravenswood, West Virginia.

$\ddagger D r$ Glueck's support for this work came from NHLBI Contract No 1-HV2-2914L (Lipid Research Clinics) and General Clinical Research Centre Grant RR00068-18.

Received 14 September 1981

Accepted 9 December 1981 animal food sources, ${ }^{23}$ many countries placed increasingly stringent restrictions on their use. In the United States occupational exposure to PCBs is now limited almost exclusively to servicing and repair of PCB-containing transformers and mining machinery; operation and servicing of hydraulic and heat transfer systems that may still be contaminated with detectable levels of PCBs despite efforts to drain and replace them with non-PCB substitutes; and recycling waste oils, sludges, and products coated with substances that contain PCBs. Inadvertent exposure may occur as well, stemming from leaks of closed-system devices such as capacitors and transformers that contain PCBs.

In 1975 the National Institute for Occupational Safety and Health (NIOSH) initiated a study of the effects of occupational exposure to PCBs. This report describes cross-sectional surveys of three groups of workers occupationally exposed to PCBs. The places of employment were an electrical equip- 
ment manufacturing plant, with exposure to $42 \%$ chlorinated biphenyl in the manufacture of electrical power capacitors; and a public and private utility company, with exposure to $54 \%$ chlorinated biphenyl in the maintenance and repair of distribution transformers. The electrical equipment manufacturing plant was chosen for study because a concurrent epidemiological study of community residents $^{45}$ provided background data on serum PCB concentrations within the general community. The two utility companies were included in the survey because the type of work performed there was thought to represent occupational exposures to PCBs that were likely to continue in the electrical industry. ${ }^{6}$

\section{Materials and methods}

STUDY SITES AND POPULATIONS

The electrical equipment manufacturing plant began operations in 1958. The production of large power capacitors was the only operation using PCBs. From 1959 to 1971 Aroclor 1242 was used; after 1971, Aroclor 1016 was used. Aroclor 1242 and 1016 are both $41-42 \%$ chlorinated biphenyls, but Aroclor 1016 has fewer biphenyl homologues with five or greater chlorine atoms per biphenyl nucleus than Aroclor 1242. ${ }^{1}$ At the time of the survey (April 1977), the impregnation fluid was being switched from PCBs to an isopropyl biphenyl. The areas of presumed greatest exposure to PCB were the capacitor-processing area (designated department " $F-30$ ") and maintenance (designated department "G-44") which required work throughout the whole plant. Data were obtained from 228 active white employees of the electrical equipment manufacturing plant: 167 hourly employees (140 men, 24 women) and 61 salaried employees (59 men, 2 women).

At the public utility company the operation with potential exposure to PCBs entailed maintenance work on transformers filled with "Askarel." Askarel contains PCBs (Aroclor 1254 or 1260) either alone or in combination with tri- or tetrachlorobenzenes, or both. Work was done on the protector and primary switches (only the primary switch contained Askarel) of about 125 transformers throughout the year. Data were obtained from 47 employees of the public utility company-14 who worked in transformer maintenance and 33 in other jobs without occupational exposure to PCBs.

At the private utility company the operations with potential exposure to PCBs were maintenance operations-that is, draining and filling operations on transformers that contained Askarel and yearly inspections of the transformers-and limited over- haul of transformers at a maintenance facility. Data were obtained from 46 employees of the private utility company-15 who worked in transformer maintenance, 10 in transformer overhaul, and 21 in other jobs without occupational exposure to PCBs.

INDUSTRIAL HYGIENE EVALUATIONS

Reports describing industrial hygiene evaluations at each facility are available from $\mathrm{ABS}$ on request. Ambient levels of airborne PCB and levels of skin contamination with PCB were measured during surveys of industrial hygiene conducted at times roughly concurrent with the medical surveys. Personal air samples were collected on florosil, a magnesium silicate absorbent, by using a Sipin SP1 pump operating at a flow rate of about $200 \mathrm{cc} / \mathrm{min}$ for two to seven hours. The PCBs were desorbed from the florosil with benzene and analysed by using a gas chromatograph with an electron capture detector. The limit of detection was $0.01 \mu \mathrm{g}$ per tube. Skin wipes were collected on Whatman smear tabs No 50 by wiping the forehead, nose, and cheek area of selected workers. The wipe samples were analysed by the same procedure to determine the amount of removable surface contamination with PCBs.

\section{CLINICAL METHODS}

The medical surveys were undertaken to determine the relation between selected clinical and biochemical findings, and plasma PCB concentration as an indicator of occupational exposure to PCB. A questionnaire was administered to each participant by a trained interviewer to obtain demographic data, and work hygiene, alcohol and tobacco consumption, family and medical histories (a copy is available from ABS on request). Present and previous occupational histories were obtained from plant employment records. A brief physical examination was performed by one of three physicians. Neither the interviewer nor physicians were blinded with respect to the jobs held by the participants.

The following determinations were performed using standard methods on blood drawn after a 12-hour fast: haematology (haemoglobin, haematocrit, leucocyte, and differential count), SMA 12/60 (serum calcium, inorganic phosphorous, glucose, urea nitrogen, uric acid, cholesterol, total protein, albumin, total bilirubin, alkaline phosphatase, lactic dehydrogenase, and glutamic-oxalacetic transaminase (SGOT)), serum glutamic-pyruvic transaminase (SGPT), serum gamma-glutamyl transpeptidase (GGTP), serum creatinine, serum direct bilirubin, serum $T-4$, serum protein electrophoresis, and blood lead. Urinary creatinine and quantitative coproporphyrin, uroporphyrin, and 
porphobilinogen were measured on spot urine specimens. Urinary glucose and protein determinations were performed at the study site by dipstick method.

Plasma total cholesterol, triglycerides (TG), and high density lipoprotein cholesterol (HDL-C) determinations were performed by the Lipid Research Centre, University of Cincinnati, following standardised Lipid Research Centre methods, ${ }^{7}$ slightly modified for HDL-cholesterol determinations. ${ }^{8}$ Low density lipoprotein cholesterol (LDL-C) levels were calculated ${ }^{9}$ in all subjects except three with triglyceride levels greater than $400 \mathrm{mg} / \mathrm{dl}$.

The clinical evaluations at the public and private utilities were identical with those described above, except that, in addition, urinary 17-ketosteroid and 17-hydroxysteroid concentrations were measured and standardised for urinary creatinine excretion on spot urines.

Serum PCB determinations were performed by Environmental Science and Engineering, Inc, in Gainesville, Florida, using a slightly modified version of an electron capture gas chromatographic procedure developed for the Office of Toxic Substances, United States Environmental Protection Agency. ${ }^{10} 11$ PCB components were quantitated as lower chlorinated biphenyls (L-PCBs) and higher chlorinated biphenyls (H-PCBs) by comparing retention times on the gas chromatogram with those of standard samples of Aroclor 1242 and Aroclor 1254. Peaks eluting before DDE (injected in the column in a pesticide mixture control) were included in the serum L-PCB determination, and those after DDE in the serum H-PCB determination. The L-PCBs so quantitated were predominantly biphenyl molecules with four or fewer chlorine atoms per molecule, and the H-PCBs were predominantly biphenyl molecules with five or more chlorine atoms per molecule. ${ }^{12}$ Major peaks that appeared in both Aroclor 1242 and 1254 standards with equivalent retention times were quantitated only once, as either serum L-PCB or serum H-PCB. Because of the similarity in composition of Aroclor 1016 and Aroclor 1242, no specific quantitation was attempted for Aroclor 1016, and instead the serum L-PCB quantitation was taken to be representative of the distribution of PCB isomers found in both these products. Because of the low concentrations of PCB, mass spectral confirmation of individual peak identity was not attempted. Quality control procedures included the analysis of two in-vitro spiked pool specimens and of one blind split duplicate in each analytical run.

STATISTICAL METHODS

Inspection of histograms and normal probability plots of the various blood tests showed that logarithmic transformation (base 10) was required to "normalise" the following data: serum L-PCB and H-PCB concentrations, SGOT, SGPT, GGTP, $\mathrm{AK}$, total and direct bilirubin, glucose, BUN, creatinine, T-4, TG, HDL-C, and LDL-C. Parametric statistical analyses were performed with the log-transformed data, using standard packaged statistical programs. ${ }^{13-15}$ Deficits in tabulations from specified total numbers of participants are attributable to missing values for data, which required elimination of the individuals with the missing values from the particular analysis.

\section{Results}

ENVIRONMENTAL PCB LEVELS

Electrical equipment manufacturing plant-The time-weighted average (TWA) personal air sample concentrations of PCBs, all obtained for workers in F-30, G-44, or an area ("miscellaneous assembly") adjacent to the impregnation ovens (located in F-30), ranged from non-detectable to $264 \mu \mathrm{g} / \mathrm{m}^{3}$, with a median of $81 \mu \mathrm{g} / \mathrm{m}^{3}$. The current OSHA standard and ACGIH threshold limit value for $42 \%$ chlorinated biphenyls are both $1000 \mu \mathrm{g} / \mathrm{m}^{3}$. Skin smear wipes of selected workers, all from F-30 or the area adjacent to F-30, ranged from $10 \mu \mathrm{g} / 100$ $\mathrm{cm}^{2}$ to $668 \mu \mathrm{g} / 100 \mathrm{~cm}^{2}$ of PCB accumulated over the course of a shift. These findings indicated workrelated skin contamination by PCBs that would not be quantified under present sampling methods, which are limited to air sampling for PCBs.

Public utility company-Two industrial hygiene surveys were conducted, one in November 1976 and the other in August 1977. During the November survey, all personal air samples for PCBs (analysed as Aroclor 1254) were under the limit of detection, -that is, under $1 \mu \mathrm{g} /$ tube, corresponding to a concentration of under $19 \mu \mathrm{g} / \mathrm{m}^{3}$. During the August 1977 survey, personal air samples for PCBs (analysed as Aroclor 1260) ranged from 37 to 215 $\dot{\mu} \mathrm{g} / \mathrm{m}^{3}$. The current OSHA standard and ACGIH threshold limit value for $54 \%$ chlorinated biphenyl are both $500 \mu \mathrm{g} / \mathrm{m}^{3}$.

Private utility company-Samples obtained during yearly inspection of transformers in underground vaults showed personal air exposures varying from 0.4 to $8.8 \mu \mathrm{g} / \mathrm{m}^{3}$. Wipe samples from the hands and face of two employees varied from $5 \mu \mathrm{g} / 100 \mathrm{~cm}^{2}$ to $487 \mu \mathrm{g} / 100 \mathrm{~cm}^{2}$. A wipe of the table top containing test equipment and the floor of the test area showed about $800 \mu \mathrm{g} / 100 \mathrm{~cm}^{2}$ for PCBs, showing localised or general smearable contamination. Personal air samples obtained during overhaul of transformers varied from 3.1 to $82.3 \mu \mathrm{g} / \mathrm{m}^{3}$. Wipe samples from 
various tools and pieces of equipment varied from non-detectable (under $0.01 \mu \mathrm{g} / 100 \mathrm{~cm}^{2}$ ) to $38 \mu \mathrm{g}$ / $100 \mathrm{~cm}^{2}$.

\section{SERUM L-PCB AND H-PCB LEVELS}

Serum geometric mean L-PCB and H-PCB concentrations, $95 \%$ confidence intervals on the means, and range, are given for survey participants at each study site (tables 1, 2). As background data, it should be noted that the arithmetical mean L-PCB and H-PCB concentrations among residents of the community in which the electrical equipment manu- facturing plant was located, without occupational or known unusual exposure to PCBs, were $11.6 \mathrm{ng} / \mathrm{ml}$ and $12.8 \mathrm{ng} / \mathrm{ml}$, respectively.

Mean serum L-PCB concentrations among workers at the electrical equipment manufacturing plant ranged from about eight to 50 times the community background level, and mean serum H-PCB concentrations ranged from about two to four times the community background level. Mean serum L-PCB concentrations were many times greater among workers at the electrical equipment manufacturing plant compared with transformer maintenance and

Table 1 Mean serum geometric mean L-PCB concentrations, 95\% confidence levels, and range

\begin{tabular}{|c|c|c|c|}
\hline Job description & No & $\begin{array}{l}\text { Geometric mean } \\
L-P C B(\text { ng/ml }) \\
\text { and } 95 \% \\
\text { confidence interval }\end{array}$ & $\begin{array}{l}\text { Range } \\
(\text { ng/ml) }\end{array}$ \\
\hline $\begin{array}{l}\text { Electrical equipment manufacturing plant } \\
\text { Current job in dept F-30 }\end{array}$ & 14 & \multirow{4}{*}{$\begin{array}{l}502 \\
306,824 \\
237 \\
137,407 \\
149 \\
118,188 \\
89 \\
77,103 \\
11 \cdot 6 \\
\text { (arithmetical mean) }\end{array}$} & $210-3330$ \\
\hline Current job in dept G-44 & 12 & & $34-2400$ \\
\hline $\begin{array}{l}\text { Current job in neither F- } 30 \text { nor G-44, } \\
\text { but ever worked in F- } 30 \text { or G-44 }\end{array}$ & 55 & & $8-1500$ \\
\hline $\begin{array}{l}\text { Current job in neither F- } 30 \text { nor G-44, } \\
\text { and never worked in F-30 or G-44 } \\
\text { Community residents }\end{array}$ & $\begin{array}{r}140 \\
89\end{array}$ & & $1-370$ \\
\hline $\begin{array}{l}\text { Public utility company } \\
\text { PCB exposed }\end{array}$ & 14 & \multirow{2}{*}{$\begin{array}{l}14 \\
15,39 \\
18 \\
15,35\end{array}$} & $5-52$ \\
\hline PCB non-exposed & 32 & & $1-59$ \\
\hline $\begin{array}{l}\text { Private utility company } \\
\text { PCB exposed }\end{array}$ & 25 & \multirow{2}{*}{$\begin{array}{l}22 \\
17,25 \\
21 \\
14,27\end{array}$} & $9-48$ \\
\hline PCB non-exposed & 22 & & $12-52$ \\
\hline
\end{tabular}

Table 2 Mean serum geometric mean $H-P C B$ concentrations, $95 \%$ confidence levels, and range

\begin{tabular}{|c|c|c|c|}
\hline Job description & No & $\begin{array}{l}\text { Geometric mean } \\
L-P C B(\mathrm{ng} / \mathrm{ml}) \\
\text { and } 95 \% \\
\text { confidence interval }\end{array}$ & $\begin{array}{l}\text { Range } \\
(\mathrm{ng} / \mathrm{ml})\end{array}$ \\
\hline $\begin{array}{l}\text { Electrical equipment manufacturing plant } \\
\text { Current job in dept F-30 }\end{array}$ & 14 & \multirow{4}{*}{$\begin{array}{l}44 \\
31,62 \\
51 \\
24,74 \\
27 \\
23,32 \\
22 \\
20,24 \\
12 \cdot 8 \\
\text { (arithmetical mean) }\end{array}$} & $20-250$ \\
\hline Current job in dept G-44 & 12 & & $10-250$ \\
\hline $\begin{array}{l}\text { Current job in neither F-30 nor G-44, } \\
\text { but ever worked in F- } 30 \text { or G-44 }\end{array}$ & 55 & & $7-130$ \\
\hline $\begin{array}{l}\text { Current job in neither F-30 nor G-44, } \\
\text { and never worked in F-30 or G-44 } \\
\text { Community residents }\end{array}$ & $\begin{array}{r}140 \\
89\end{array}$ & & $1-110$ \\
\hline $\begin{array}{l}\text { Public utility company } \\
\text { PCB exposed }\end{array}$ & 14 & \multirow{2}{*}{$\begin{array}{l}24 \\
15,39 \\
7 \\
4,10\end{array}$} & $7-24$ \\
\hline PCB non-exposed & 32 & & $1-19$ \\
\hline $\begin{array}{l}\text { Private utility company } \\
\text { PCB exposed }\end{array}$ & 25 & \multirow{2}{*}{$\begin{array}{l}29 \\
20,43 \\
8 \\
5,11\end{array}$} & $7-250$ \\
\hline PCB non-exposed & 22 & & $3-25$ \\
\hline
\end{tabular}


repair workers, while mean serum $\mathrm{H}-\mathrm{PCB}$ concentrations among workers at the electrical equipment manufacturing plant more closely resembled concentrations among the transformer maintenance and repair workers.

The relation of serum $\log (\mathrm{L}-\mathrm{PCB})$ and $\log (\mathrm{H}-$ PCB) concentrations, and personal air levels of PCBs, was examined among workers at the electrical equipment manufacturing plant. Time-weighted average personal air level exposure measurements were available for 10 job descriptions, to which 20 participants in the survey were assigned. The correlation of personal PCB air levels with serum $\log (\mathrm{L}-$ PCB) concentration was significant $(r=0.66, p=$ 0.0013 ); but the correlation of personal PCB air levels with serum $\log (\mathrm{H}-\mathrm{PCB})$ concentration was not $(r=0.37, p=0 \cdot 11)$. The lack of statistical significance of the latter correlation may well have been a function of the size of the data set available for the analysis. Data were not available to permit similar analyses for the transformer maintenance and repair workers.

The use of protective equipment (protective clothes, gloves, and respirators) increased with personal air level exposure. Thus, while a significant positive correlation between the use of protective equipment and serum $\log (\mathrm{L}-\mathrm{PCB})$ and $\log (\mathrm{H}-\mathrm{PCB})$ concentrations could be shown (data not given), the primary association was likely between personal air level exposure and the use of protective equipment rather than the use of protective equipment and serum $\log (\mathrm{PCB})$ concentration.

\section{QUESTIONNAIRE DATA}

The relationships between serum PCB concentration and response to questions concerning symptoms and past illnesses were examined. Age and study site were potential confounding variables that had to be taken into account in the analysis, so that it might reasonably be inferred that any observed associations had not resulted from the effect of the confounding variables alone. The questionnaire response data were analysed by a logistic regression in which the logarithm of the odds for a positive ("Yes") response for the dichotomous variable (questionnaire response) was modelled as a linear function of independent predictor variables, such as serum $\log (\mathrm{L}-\mathrm{PCB})$ and $\log (\mathrm{H}-\mathrm{PCB})$ concentrations, as well as the confounders' age and study site. The following histories of symptom were significantly associated with either serum $\log (\mathrm{L}-\mathrm{PCB})$ or $\log (\mathrm{H}-$ PCB) concentration, or both, in the presence of the confounders (see table below).

\section{PHYSICAL EXAMINATIONS}

No consistent patterns of abnormalities were noted on physical examination at any study site. None of the participants was found to have acneform lesions suggestive of chloracne. Although a correlation was noted between serum $\log (\mathrm{H}-\mathrm{PCB})$ concentration and diastolic blood pressure at the electrical equipment manufacturing plant $\left(r=0 \cdot 1395, F_{1,219}=\right.$ 4.61), multiple linear regression including the additional confounding variables age and sex showed the apparent association of diastolic blood pressure with increasing serum $\log (\mathrm{H}-\mathrm{PCB})$ concentration to have been attributable to an association primarily with age (partial $r=0.2742, F_{1,217}=17.64$ ) as well as with sex (partial $r=0 \cdot 1381, F_{1,217}=4 \cdot 27$ ).

\section{LABORATORY DATA-BLOOD TESTS}

Simple correlations between serum $\log (\mathrm{L}-\mathrm{PCB})$ and $\log (\mathrm{H}-\mathrm{PCB})$ concentrations and the results of clinical biochemistry and haematological tests were computed for participants at each study site separately. Statistically significant correlations are summarised in table 3. To control for confounding by age (and sex, at the electrical equipment manufacturing plant), multiple linear regression equations were computed for each statistically significant correlation, with serum $\log (\mathrm{PCB})$ concentration, age, and (at the electrical equipment manufacturing plant only) sex as independent variables. Because of the collinearity of serum $\log (\mathrm{L}-\mathrm{PCB})$ and $\log (\mathrm{H}-$ PCB) concentrations, separate regressions were computed, with serum $\log (\mathrm{L}-\mathrm{PCB})$ and the confounder(s) as predictors, and serum $\log (\mathrm{H}-\mathrm{PCB})$ and the confounder(s) as predictors. The squared partial correlations, "partial $\mathbf{R}^{2}$," were computed. This is a measure of the variance of the outcome variable still to be accounted for by serum $\log (\mathrm{PCB})$ concentration, relative to the variance already

\begin{tabular}{llr}
\hline Symptom & $\begin{array}{l}\text { Associated with log }(L-P C B) \\
\text { level in presence of } \\
\text { confounders } \sim \chi^{2}(1)^{*}\end{array}$ & $\begin{array}{l}\text { Associated with log(H-PCB) } \\
\text { level in presence of } \\
\text { confounders } \sim \chi^{2}(1)^{*}\end{array}$ \\
\hline Coughing on the job or soon after work & $5 \cdot 05$ & $3 \cdot 87$ \\
Irritated or burning eyes & $7 \cdot 66$ & $11 \cdot 29$ \\
Unexplained loss of appetite & $5 \cdot 70$ & $3 \cdot 40$ \\
Unexplained tingling in the hands & $5 \cdot 16$ & $3 \cdot 51$ \\
Rash or dermatitis & 0.04 & $4 \cdot 51$ \\
\hline
\end{tabular}

${ }^{*} \operatorname{Pr}\left(\chi^{2}(1) \geqslant 3 \cdot 84\right)=0 \cdot 05$. 
Table 3 Product-moment correlations between selected clinical biochemistries and haematologies and serum log $(L-P C B)$ and $\log (H-P C B)$ concentrations, by study site

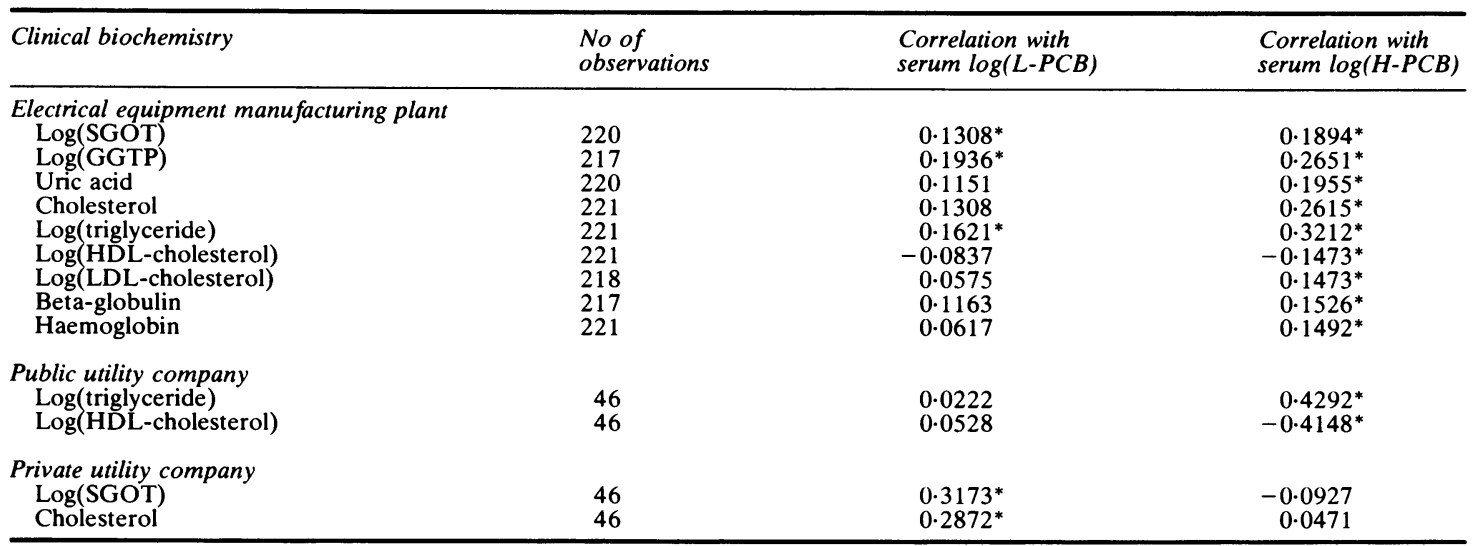

* Statistically significant $(p<0 \cdot 05)$ correlation.

accounted for by the regression on the confounders alone. ${ }^{16}$ The results are summarised in table 4.

Neither serum $\log (\mathrm{L}-\mathrm{PCB})$ nor $\log (\mathrm{H}-\mathrm{PCB})$ concentrations were significant predictors of serum uric acid, beta-globulin, LDL-cholesterol, or haemoglobin when confounding variables age and sex were taken into consideration. Significant partial correlations, however, in the presence of the confounding variables, between $\log ($ SGOT $), \log ($ GGTP), cholesterol, $\log$ (triglyceride), and $\log ($ HDL-cholesterol); and either serum $\log (\mathrm{L}-\mathrm{PCB})$ or $\log (\mathrm{H}-\mathrm{PCB})$ concentrations, were still shown at at least one site.

Given the same data available at three sites, it would be reasonable to expect meaningful correlations/associations to be found at more than one site. Accordingly, homogeneity of trend was investigated across all three sites by an analysis of covariance. The results are summarised in table 5. It is apparent that $\log (\mathrm{SGOT}), \log ($ GGTP $), \log ($ triglyceride), and $\log (\mathrm{HDL}-\mathrm{cholesterol})$ were

Table 4 Partial correlations between clinical biochemistries and serum $\log (L-P C B)$ and $\log (H-P C B)$ concentrations, by study site

\begin{tabular}{|c|c|c|}
\hline Clinical biochemistry & $\begin{array}{l}\text { Correlation with } \\
\text { serum } \log (L-P C B)\end{array}$ & $\begin{array}{l}\text { Correlation with } \\
\text { serum } \log (H-P C B)\end{array}$ \\
\hline $\begin{array}{l}\text { Electrical equipment manu facturing plant } \\
\text { Log(SGOT) } \\
\text { Log(GGTP) } \\
\text { Uric acid } \\
\text { Cholesterol } \\
\text { Log(triglyceride) } \\
\text { Log(HDL-cholesterol) } \\
\text { Log(LDL-cholesterol) } \\
\text { Beta-globulin } \\
\text { Haemoglobin }\end{array}$ & $\begin{array}{c}0 \cdot 1085 \\
0 \cdot 1618^{*} \\
0 \cdot 0037 \\
0 \cdot 0899 \\
0 \cdot 1234 \\
-0 \cdot 0449 \\
0 \cdot 0001 \\
0 \cdot 0086 \\
0 \cdot 0000\end{array}$ & $\begin{array}{c}0 \cdot 1579^{*} \\
0 \cdot 2017^{*} \\
0 \cdot 0101 \\
0 \cdot 1822^{*} \\
0 \cdot 2526^{*} \\
-0.0887 \\
0.0027 \\
0 \cdot 0128 \\
0.0028\end{array}$ \\
\hline $\begin{array}{l}\text { Public utility company } \\
\text { Log(SGOT) } \\
\text { Log(GGTP) } \\
\text { Cholesterol } \\
\text { Log(triglyceride) } \\
\text { Log(HDL-cholesterol) } \\
\text { Log(LDL-cholesterol) }\end{array}$ & $\begin{array}{r}0.1436 \\
0.0724 \\
-0.0827 \\
0.0819 \\
0.0242 \\
-0.0111\end{array}$ & $\begin{array}{c}-0.1753 \\
-0.0777 \\
-0.2020 \\
0.5182^{*} \\
-0.4403^{*} \\
0.0474\end{array}$ \\
\hline $\begin{array}{l}\text { Private utility company } \\
\text { Log(SGOT) } \\
\text { Log(GGTP) } \\
\text { Cholesterol } \\
\text { Log(triglyceride) } \\
\text { Log(HDL-cholesterol) } \\
\text { Log(LDL-cholesterol) }\end{array}$ & $\begin{array}{l}0 \cdot 3182^{*} \\
0 \cdot 0859 \\
0 \cdot 3227^{*} \\
0 \cdot 2661 \\
0 \cdot 0929 \\
0 \cdot 0421\end{array}$ & $\begin{array}{r}-0.1242 \\
-0.2115 \\
-0.0357 \\
-0.0494 \\
-0.1425 \\
0.0007\end{array}$ \\
\hline
\end{tabular}

* Statistically significant $(p<0.05)$ correlation. 
Table 5 Inter-site comparisons of correlations: homogeneity of trend of selected clinical biochemistries with serum $\log (L-P C B)$ and $\log (H-P C B)$ plus confounders

\begin{tabular}{|c|c|c|c|c|}
\hline \multirow[t]{2}{*}{$\begin{array}{l}\text { Clinical } \\
\text { biochemistry }\end{array}$} & \multicolumn{2}{|c|}{$\begin{array}{l}\text { Regression on serum } \log (L-P C B) \\
\text { plus confounders }\end{array}$} & \multicolumn{2}{|c|}{$\begin{array}{l}\text { Regression on serum } \log (H-P C B) \\
\text { plus confounders }\end{array}$} \\
\hline & Homogenous trend? & Significant trend? & Homogenous trend? & Significant trend? \\
\hline $\begin{array}{l}\log (\text { SGOT }) \\
\text { Log(GGTP }) \\
\text { Cholesterol } \\
\text { Log(triglyceride }) \\
\text { Log(HDL-cholesterol) }\end{array}$ & $\begin{array}{l}\text { Yes } \\
\text { Yes } \\
\text { Yes } \\
\text { Yes } \\
\text { Yes }\end{array}$ & $\begin{array}{l}\text { Yes } \\
\text { Yes } \\
\text { No } \\
\text { Yes } \\
\text { No }\end{array}$ & $\begin{array}{l}\text { Yes } \\
\text { No } \\
\text { No } \\
\text { No } \\
\text { Yes }\end{array}$ & $\begin{array}{l}\text { No } \\
\text { No } \\
\text { No } \\
\text { Yes } \\
\text { Yes }\end{array}$ \\
\hline
\end{tabular}

significantly associated with either serum $\log (\mathrm{L}-$ PCB) or $\log (\mathrm{H}-\mathrm{PCB})$ concentrations, or both across all three sites. The trend was homogeneous for $\log ($ SGOT $)$ regressed on $\log (\mathrm{L}-\mathrm{PCB}), \log (\mathrm{GGTP})$ regressed on $\log (\mathrm{L}-\mathrm{PCB}), \log$ (triglyceride) regressed on $\log (\mathrm{L}-\mathrm{PCB})$, and $\log (\mathrm{HDL}$-cholesterol) regressed on $\log (\mathrm{H}-\mathrm{PCB})$. The trend was not homogeneous for $\log ($ triglyceride) regressed on $\log (\mathrm{H}-\mathrm{PCB})$. Biochemistries for which nonhomogeneity of trend was noted in the absence of significant trend were of no practical interest.

\section{LABORATORY DATA-URINE TESTS}

Urinary glucose, protein, porphyrin, and steroid excretion were not correlated with either serum L-PCB or H-PCB concentrations.

\section{Discussion}

Serum $\log (\mathrm{PCB})$ correlated significantly with symptoms suggestive of mucous membrane and skin irritation, of systemic malaise, and of altered peripheral sensation; and with serum $\log ($ SGOT $), \log ($ GGTP), plasma $\log$ (triglyceride), and $\log$ (HDL-cholesterol). These correlations occur in the absence of overt clinical dysfunction identifiable on physical examinations. The simultaneous changes in SGOT, GGTP, plasma triglyceride, and HDL-cholesterol are evidence of an effect on the liver of exposure to PCB, the biological significance of which is not clear. A positive correlation between serum GGTP and triglyceride has been described, ${ }^{17}$ as has the rise of serum GGTP in the presence of drugs known to induce liver microsomal enzymes. ${ }^{18}$ It has been suggested that the positive association of GGTP and triglyceride may reflect hepatic microsomal enzyme induction, with an increase in the hepatic content of enzymes related to triglyceride synthesis. ${ }^{19}$ In support of this conjecture, PCBs are well known to induce hepatic microsomal (mixed function oxidase) enzymes both in laboratory animals ${ }^{20}$ and in man. ${ }^{21}$ Therefore, alterations in liver enzyme tests in association with increasing serum PCB concentration may not themselves be predictive of future chronic liver disease but may reflect liver micro- somal enzyme induction. It should be emphasised, however, that the consistent inverse associations of $\log (\mathrm{H}-\mathrm{PCB})$ with $\log (\mathrm{HDL}-\mathrm{cholesterol})$ at all three worksites may have long-term cardiovascular significance, given the significant inverse, independent associations of HDL-cholesterol with coronary artery disease. ${ }^{22}$

In general, a lack of clinically apparent illness among workers with high levels of exposure to PCB and high serum PCB concentrations seems to have been the rule. ${ }^{23-27}$ None the less, correlations of exposure to PCB or serum PCB concentrations have been reported with various clinical biochemical tests in the absence of clinically detectable disease, including positive correlations with $\mathrm{SGOT}^{24}{ }^{26}$ and GGTP $^{28}$ (Avitto V N. 15th annual meeting of US Public Health Service Professional Association, Houston, 26-29 May 1980), negative correlation with serum bilirubin, ${ }^{29}$ and positive correlations with plasma cholesterol ${ }^{28}$ and triglyceride. ${ }^{5031}$ More recently, however, findings of "dermatotoxicity" in association with increasing plasma PCB concentrations, and of increasing serum triglyceride concentrations in association with increasing plasma PCB concentrations, have been reported. ${ }^{32}$ Two reports $^{33}{ }^{34}$ from Italy have documented, among workers exposed to $54 \%$ chlorinated biphenyl in the manufacture of electrical capacitors, signs of "hepatotoxicity" (primarily hepatomegaly) along with rises of liver enzyme tests and four cases of chloracne (among 80 workers). No "definite association" was found between chloracne and blood PCB concentration. By contrast, abnormal liver enzyme tests and blood PCB concentrations, particularly trichlorobiphenyl blood concentrations, were positively associated.

One would expect that adverse human health effects from exposure to PCB, if they exist, would most readily be identified in groups with the greatest exposures (excluding poisoning attributable to accidental contamination of food). None of the published occupational or epidemiological studies (including ours), however, have shown that occupational exposure to PCBs is associated with any adverse health outcome, to be distinguished from 
demonstrable subclinical biochemical alterations. An exception to this is the occurrence of chloracne during the early years of its manufacture and use, and possibly currently as well, depending on circumstances of its use and exposure. This inability to show convincingly an adverse effect on human health from occupational exposure to PCBs may be partially attributable to the often encountered confusion of multiple chemical exposures in the workplace or in the general environment, which either directly or in combination, influence the health of exposed individuals. It is necessary to recognise, however, that clinical and epidemiological methods generally are not available that are sufficiently sensitive and specific to allow a high degree of confidence that, when no significant individual or group effects have been found, an adverse health effect still has not been overlooked.

None the less, it is reasonable to emphasise the following observations that may have implications for a recommended standard for occupational exposure to PCBs.

(1) Occupational exposure to PCBs may result in surprising rises in serum PCB concentrations among exposed workers (as in the electrical equipment manufacturing plant). Even for periodic low-level occupational exposure to PCBs (the two utility companies), demonstrable increases in workers' serum PCB concentrations could be identified.

(2) Contamination of the skin with PCBs could be documented. Such contamination might constitute a significant source of occupational exposure to PCBs, even though such contamination is not readily quantifiable by routine industrial sampling methods. Although air level monitoring does not reflect the sole route of occupational exposure to PCB, environmental control based on PCB air level measurements, coupled with adherence to work practices intended to limit PCB skin and environmental contamination, would probably provide a reasonable and acceptable approach to controlling exposure and absorption of PCB.

(3) Statistically significant correlations of certain symptoms, serum $\log ($ SGOT $), \log ($ GGTP), plasma $\log$ (triglyceride), and $\log (\mathrm{HDL}$-cholesterol) with serum $\log (\mathrm{PCB})$ concentrations may be shown. These correlations remain significant when comparisons are made across three study sites widely separated in geographical distance.

Although the meaning of these changes for the long-range health outcome of workers exposed to PCBs is open to speculation, these trends suggest that occupational exposure to PCB should be minimised. Unfortunately, data collected at one point in time do not allow the estimation of the correlation between serum PCB concentrations and
PCB personal air exposures that prevailed at times before the survey, and the data in themselves do not provide evidence to suggest a specific permissible exposure limit.

\section{References}

' Lloyd JW, Moore RM, Woolf BS, Stern HP. Polychlorinated biphenyls. JOM 1976;18:109-13.

${ }^{2}$ Higuchi K, ed. $P C B$ poisoning and pollution. New York: Academic Press, 1976.

${ }^{3}$ Spaulding JE, Wessel JR. Occurrence and sources of PCBs in food. In: Interdepartmental task force on PCBs. Polychlorinated biphenyls and the environment. Springfield, Va: US Department of Commerce, 1972.

${ }^{4}$ Bergh AK, Peoples AS. Distribution of polychlorinated biphenyls in a municipal wastewater treatment plant and environs. Science of the Total Environment 1977;8:197-204.

${ }^{5}$ Baker EL Jr, Landrigan PJ, Glueck CJ, et al. Metabolic consequences of exposure to polychlorinated biphenyls (PCB) in sewage sludge. Am J Epidemiol 1980;112:553-63.

- Environmental Protection Agency. Polychlorinated biphenyls (PBCs): toxic substances control. Federal Register 1977;42:26564-77.

${ }^{7}$ Lipid Research Clinics Program. Manual of laboratory operations 1974. Washington DC: 1975. (DHEW Publication No (NIH) 75-628.)

${ }^{8}$ Ishikawa TT, Brazier JB, Steiner PM, Stewart LE, Gartside PS, Glueck CJ. A study of the heparin-manganese chloride method for determination of plasma alpha-lipoprotein cholesterol concentration. Lipids 1976;11:628-33.

${ }^{9}$ Friedewald WT, Levy RI, Fredrickson DS. Estimation of the concentrations of low-density lipoprotein cholesterol in plasma without use of the preparative ultracentrifuge. Clin Chem 1972;18:499-502.

${ }^{10}$ Environmental Sciences and Engineering, Inc. Analysis of polychlorinated biphenyl (PCB) in human blood serum samples. Final report. Gainesville, Florida: ECEI, 1977. (Research request No 2, EPA contract 68-01-3248.)

"Taylor DG, ed. NIOSH manual of analytical methods. Cincinnati, Ohio: DHHS(NIOSH) 1980. (DHHS(NIOSH) publication No 80-125.)

12 Hutzinger O, Safe S, Zitko V. The chemistry of PCBs. Cleveland: Chemical Rubber Co Press, 1974.

${ }^{13}$ SAS Institute. SAS user's guide. 1979 ed. Raleigh, North Carolina: SAS Institute, 1979.

14 SAS Institute. SAS supplemental library user's guide. 1980 ed. Cary, North Carolina: SAS Institute, 1980.

is Dixon WJ, ed. BMDP-biomedical computer programs. Berkeley: University of California Press, 1977.

${ }^{10}$ Green PE. Analyzing multivariate data. Chap 2. Hinsdale, Illinois: Dryden Press, 1978.

17 Martin PJ, Martin JV, Goldberg DM. Gamma-glutamyl transpeptidase, triglycerides, and enzyme induction. $\mathrm{Br} \mathrm{Med} J$ 1975;i:17-8.

18 Whitfield JB, Pounder RE, Neale G, Moss DW. Serum gammaglutamyl transpeptidase in liver disease. Gut 1972;13:702-8.

${ }^{19}$ Ferrari C, Testori GP, Scanni A, Frezzati S, Bertazzoni A. Rommussi M. Reduction of serum alkaline phosphatase and gamma-glutamyl transpeptidase activities by short-term clofibrate $N$ Engl J Med 1976;295:449.

${ }^{20}$ Goldstein JA. The structure-activity relationships of halogenated biphenyls as enzyme inducers. Ann NY Acad Sci 1979;320: $164-78$.

${ }^{21}$ Alvares AP, Fischbein A, Anderson KE, Kappas A. Alterations in drug metabolism in workers exposed to polychlorinated biphenyls. Clin Pharmacol Ther 1977;22:140-6.

22 Castelli WP, Doyle JT, Gordon T, et al. HDL-cholesterol and 
other lipids in coronary heart disease. The co-operative lipoprotein phenotyping study. Circulation 1977;55:767-72.

${ }^{23}$ Hasagawa $H$, Sato M, Tsuruta $H$. Report of survey of work area environment while PCB is handled and of the health of workers handling PCB. In: Special report on prevention of environmental pollution by PCB-like substances. Japan: Research Coordination Bureau, Science and Technology Agency, 1972:141-99.

${ }^{24}$ Karppanen E, Kolho L. The concentration of PCB in human blood and adipose tissue in three different research groups. In: PCB conference II, Stockholm, 1972. Stockholm: National Swedish Environmental Protection Board, 1973:124-8.

${ }^{25}$ Ouw KH, Simpson GR, Siyali DS. The use and health effects of Aroclor 1242, a polychlorinated biphenyl in the electrical industry. Arch Environ Health 1976;31:189-94.

${ }^{20}$ Crow KD. Chloracne. A critical review including a comparison of two series of cases of acne from chloronaphthalene and pitch fumes. Trasactions of the St John's Hospital Dermatological Society 1970;56:79-99.

${ }^{27}$ Fischbein A, Woolf MS, Lilis R, Thornton J, Selikoff IJ. Clinical findings among PCB-exposed capacitor manufacturing workers. Ann NY Acad Sci 1979;320:703-15.

${ }^{28}$ Kreiss K, Zack MM, Kimbrough RD, Needham LL, Smrek AL,
Jones BT. Association of blood pressure and polychlorinated biphenyl levels. JAMA 1981;245:2505-9.

${ }^{29}$ Hirayama C, Okumura M, Hagai J, Masuda Y. Hypobilirubinemia in patients with polychlorinated biphenyls poisoning. Clin Chem Acta 1974;55:97-100.

${ }^{30}$ Nagai J, Furukawa M, Yae Y, et al. Clinico-chemical investigation of chlorobiphenyls poisoning, especially in the serum lipid analysis of the patients. Fukuoka Acta Medica 1969;60:475-9.

${ }^{31}$ Uzawa H, Notori A, Nakamuta S, Ikeura Y. Consecutive threeyear follow-up study of serum triglyceride concentrations of 82 subjects with PCB poisoning. Fukuoka Acta Medica 1973;63:401-4.

${ }^{32}$ Chase $\mathrm{KH}$. Clinical and metabolic abnormalities in occupational exposure to polychlorinated biphenyls (PCBs). JOM 1981;23:305.

${ }^{33}$ Maroni M, Colombi A, Cantoni S, Ferioli E, Foa V. Occupational exposure to polychlorinated biphenyls in electrical workers. I Environmental and blood polychlorinated biphenyls concentrations. $\mathrm{Br} J$ Ind Med 1981;38:49-54.

${ }^{34}$ Maroni M, Colombi A, Cantoni S, Ferioli E, Foa V. Occupational exposure to polychlorinated biphenyls in electrical workers. II Health effects. $\mathrm{Br} J$ Ind Med 1981;38:55-60. 